\title{
The Bimbia-Bonadikombo Community Forest, South West Region of Cameroon: Biodiversity Potentials, Problems and Prospects
}

\author{
${ }^{1}$ Dr. Robert Njilla Mengnjo Ngalim \& ${ }^{2}$ Simbo Terence \\ ${ }^{1}$ Lecturer / Consultant on Specified Assignment, Department of Development Studies, \\ Pan African Institute for Development, West Africa, Cameroon. \\ ${ }^{2}$ Advanced Level Geography Tutor, Government Bilingual Secondary School Mbelenka, \\ Lebialem Division, Cameroon. \\ Injillamn@yahoo.com, ${ }^{2}$ simboterence@yahoo.com
}

\begin{abstract}
This paper has examined the Bimbia-Bonadikombo Community Forest of the South West Region of Cameroon in terms of its biodiversity potentials, problems or challenges involved in forest exploitation and management, and the prospects, so as to bridge the gap between forest exploitation, conservation and sustainable livelihoods. Data for this study were collected using primary and secondary techniques. Participatory Rural Appraisal techniques such as field observations, administration of questionnaires and interviews constituted the main primary data collection techniques. Secondary data, published or unpublished, were also important in this study. The findings revealed that the Bimbia-Bonadikombo Community Forest $(B B C F)$ is rich in biodiversity potentials of flora and fauna, though some of which are either threatened or endangered by increasing human activities. There is the continuous proliferation of illicit activities within and around the forest which have led to degradation of the forest and its biodiversity over the years. This has been a major challenge as members of the management committee work hard to bridge the gap between forest conservation on the one hand, and livelihood sustenance through forest exploitation on the other. The findings also revealed the Strengths, Weaknesses, Opportunities and Threats (SWOT) to the sustainability of the forest based on the views of the entire population and those of the forest management committee members. The main recommendation is in line with the continuous drive to reinforce the legislation on restricting illicit activities within and around this community forest, which falls in line with the concept of protected area management. The demarcated boundaries should be patrolled periodically so as to check illegal activities perpetuated in the forest.
\end{abstract}

Keywords: Bimbia- Bonadikombo, Community Forest, Biodiversity Potentials, Problems and Prospects, SWOT Analysis, Livelihood Sustenance, Cameroon.

\section{INTRODUCTION}

Cameroon is often referred to as "Africa in miniature". This is because of the great cultural, ethnic and geographical diversity of the country. This natural diversity is believed to have favoured the existence of one of the richest ecological communities (Sunderlin, et al., 2005; Sunderland et al., 2002). Cameroon's forests are estimated to cover 22.5 million hectares of which 14 million hectares are tropical rain forest and 8 million in the savannah biome (Mesmin et al., 2009; CAMPER/USAID, 1993). For several decades today, biodiversity decline in the tropics has received global attention. The threat to species and ecosystems has greatly increased in recent times (Mesmin et al, 2009; Sunderlin et al., 2005; Mcneely, et al., 1990). Virtually all of them are caused by human mismanagement of biological resources, often stimulated by poorly articulated economic policies and faulty institutions that enable the evasion of exploiters to pay the costs of exploiting the forest. Providing solutions to the problem of biodiversity degradation depend above all on how the problem is defined. Such problems are generally defined in terms of insufficient areas, excessive hunting, poor law enforcement, land encroachment and illegal trade in forest resources (Mesmin and Fogwe, 2009; Ndenecho, 2005; Balgah, 2001; Denniston, 1995; Jaff, 1994). These definitions warrant possible responses which include establishing more protected areas, improving standards of managing species and protected areas, enacting national forest protection laws, enacting international legislation, controlling trade in endangered species and policing of protected areas. The decline in biodiversity is 
a precarious problem for the conservation of the natural environment (Ndenecho, 2005; Sunderland, et al., 2002).

Protected areas in several countries have been ruined when their vital ecological aspects have not been taken into consideration (Lambi et al, 2012; Mesmin et al., 2009, Mesmin \& Fogwe, 2009). In most developing countries, the purpose of conservation is to preserve biodiversity and so have failed to acknowledge the realities of their local socio-cultural and economic environments (Delénè, et al., 2009; Ndenecho, 2007). Research has been carried out on protected areas with special focus on tourism, ecotourism, and how protection of local ethnicity can be achieved without impacting on the life of the local people. In this paper, the potentials for sustainable development of the BimbiaBonadikombo Community Forest have been assessed. This study on its part was intended to examine the problems and prospects and to suggest sustainable practices likely to be beneficial for the local inhabitants. The paper also emphasizes the need for ecological planning and linking of local livelihoods with environmental protection projects and initiatives.

\section{THE STUDY AREA}

The Bimbia-Bonadikombo Community Forest (BBCF) is situated in the eastern part of Limbe, South West Region, Cameroon. The forest has direct motorable access through Down Beach. The BBCF was created on May 18, 2002 and comprises 5 villages which include: Bonadikombo, Bonabile, Bonangombe, Liwanda and Dikolo (Map 1). The forest is bordered by Mandolin to the north, through Mile Four and Tomatal behind Moliwe CDC palms plantations. It stretches from the Ombe River down through Camps 3 and 2 of the CDC Rubber Plantations to the road. It further extends along the road to Bimbia, Mabeta and Jamstone River to the coast by the east and the Atlantic Ocean to the south. It has a surface area of 3,735 hectares (Bimbia-Bonadikombo Forest Management Plan Document and Nuesiri, 2008). Since this community forest is already part of a protected area, its areal extent has not reduced over time. However, it has witnessed an increase in the proliferation of illicit activities, leading to degradation of the forest.

The Bimbia- Bonadikombo Community that resides adjacent to the forest has always depended on products harvested from the forest. Over the past years, the uses of these products have evolved from basically traditional and subsistence to more economic driven to support the livelihood of the people (Nuesiri, 2008). Demands in the BBCF are made by different groups of people, local institutions and users. The BBCF area is unique for its mixture of stakeholders as opposed to other areas in the Mount Cameroon region, which are mainly homogeneous. The heterogeneity of the area stems from the diverse economic activities and varied tribal groups within the adjacent villages. Human activities are increasingly fragmenting, degrading and isolating the remaining forest patches in the BBCF. The main objective of this study was to ensure sustainable forest resource management with emphasis on natural regeneration, the involvement of the local people and the promotion of sustainable livelihoods by implementing the 1994 forestry laws and guidelines. The laws recognize the creation of buffer zones around all protected areas. These regions adjacent to protected areas, which provide local communities with sustainable income generating activities such as poaching/hunting, farming, timber exploitation and NTFPs collection, are important in the forest conservation process.

\section{Methodology}

The research design for the study was basically the participatory (rapid) rural appraisal, due to its advantages of yielding results within a short time, low cost of data collection and high reliability of the data collected. This research design was chosen because it is considered as one of the popular and effective approaches to gather information in rural areas or communities with a high level of communality. This approach operates on the basis of a paradigm shift from the top-down to the bottom-up approach, and from blueprint to the learning process. The technique was based on participation of the stakeholders, flexibility in terms of incorporating their time schedules into decisions concerning when to collect data from them, team work, optimal ignorance and systematic. The precise techniques used included the participatory mapping, transect walks and guided field walks, semi-structured interviewing and field questionnaires.

The study focused on the Bimbia-Bonadikombo Community Forest and the forest adjacent villages. Study methods included field observations, data collection and evaluation, using a SWOT analysis. A database of the reserve was used to derive data on biodiversity resources. Field observations, informal interviews, questionnaires and secondary data sources yielded data on biodiversity potentials. Field 
observations were conducted in the communities within and around the forest area, and also a transect walk was carried out in the various compartments of the forest, to have firsthand knowledge and experience of the activities going on within the forest. This technique was complementary when conducting the SWOT analysis.

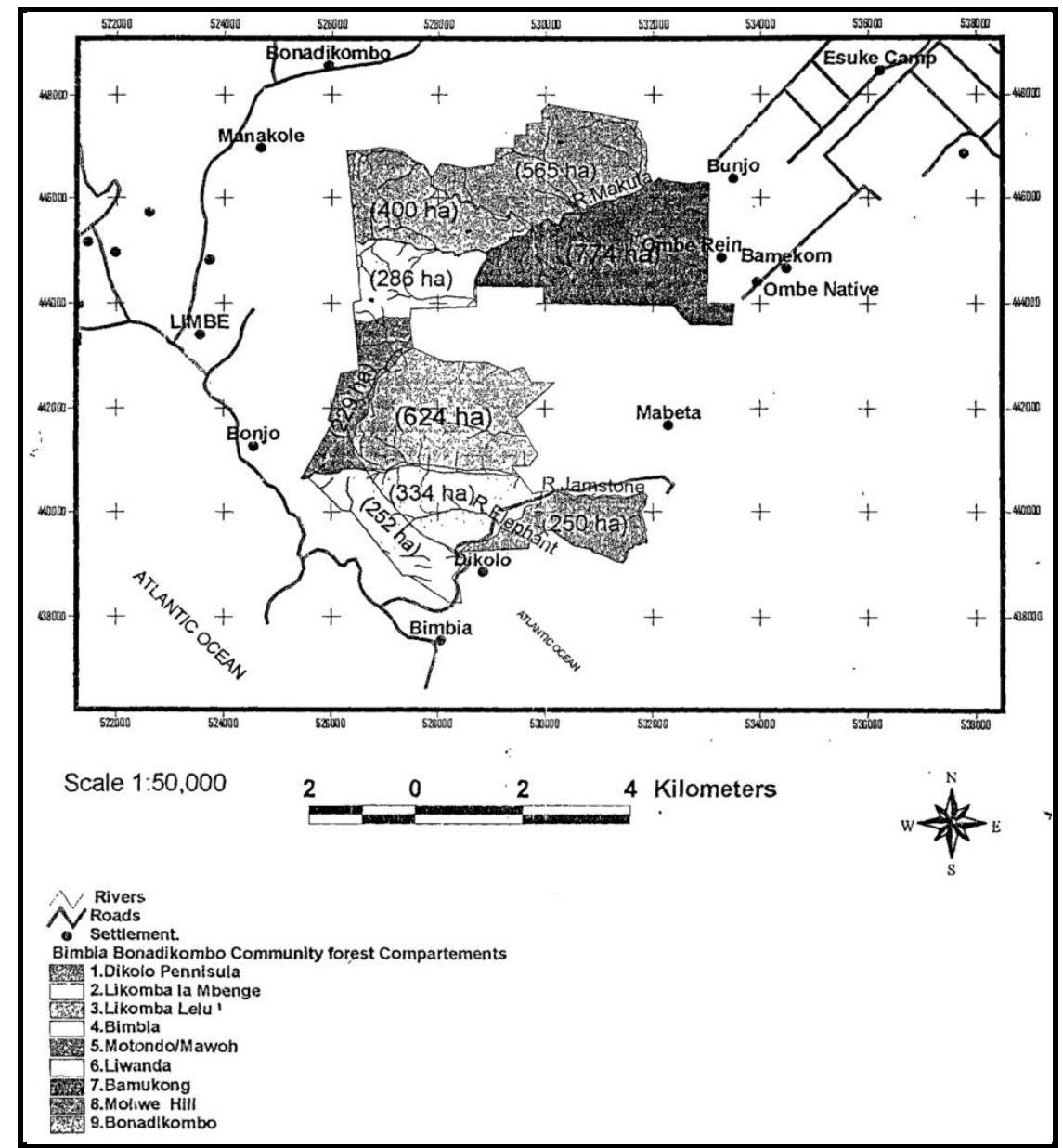

Map1. Compartment Boundaries for Bimbia-Bonadikombo Community Forest

Source: Simple Management Plan for BBCF for the period 2002 - 2027

The questionnaires focused on the main forest management unit and how they relate to the management of protected areas. The local communities adjacent to the protected areas with forest depended livelihoods were also investigated. Questionnaires were administered, which focused on the identification of livelihood activities, forest users in the protected areas and exploitation techniques. A total of 300 questionnaires were administered, 30 each to the various compartments of the forest and the remaining 30 among the members of the Bimbia-Bonadikombo Community Forest Management Council or the forest leaders in the various communities. Field observations were buttressed with the use of informal interviews with key informants to identify human activities, their impacts on the forest and possible mitigation strategies.

The study was complemented with secondary source data from the Bimbia-Bonadikombo Natural Resource Management Council and Bimbia-Bonadikombo Community Forest Management Plan. The data obtained were analyzed using descriptive statistical techniques such as frequencies and percentages. The SWOT analysis focused on the nine forest adjacent villages. The advantages and disadvantages of the reserve were brought out. The analysis was done by determining the strengths, weaknesses, opportunities and threats, so that strategic suggestions could be presented for ecological planning, monitoring and overall sustainability.

\section{RESUlTS AND DISCUSSION}

BBCF is divided into nine compartments for management purposes. Three of these compartments (Dikolo, Likomba la Mbenge and Likomba Lelu), with a surface area of 1200 ha, have been set aside for research, ecotourism and environmental education activities as shown on Map 2. 


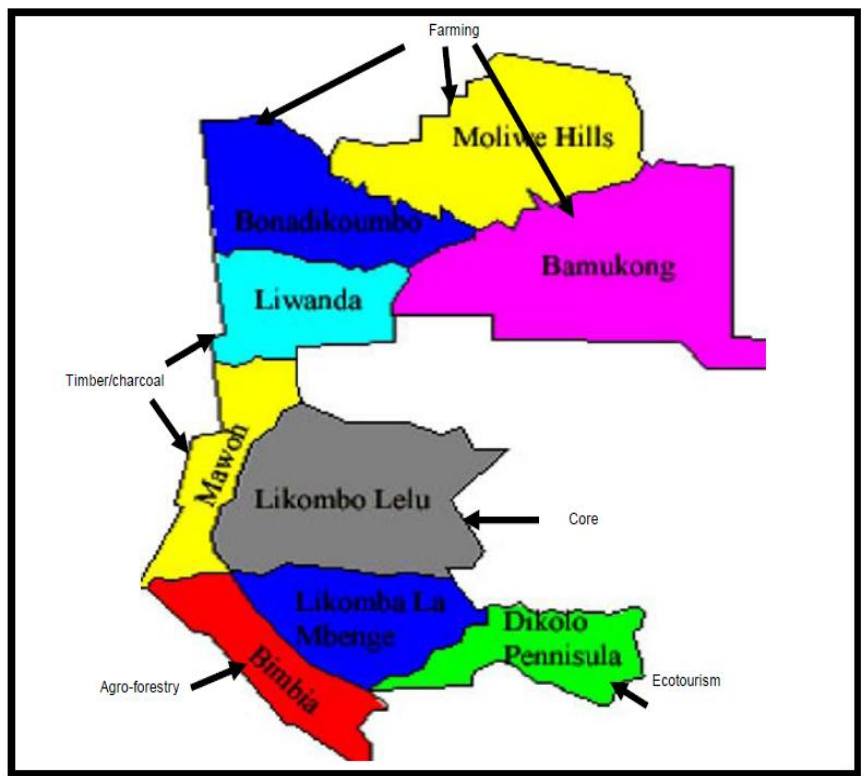

Map 2. The nine (09) compartments of the Bimbia-Bonadikombo Community Forest

Source: Simple Management Plan for BBCF for the period 2002 - 2027

\section{Vegetation Types and Ecosystems}

The vegetation consist of degraded forest, plantations and farmlands. The Bimbia-Bonadikombo Community Forest is dominated by six (06) main vegetation types which include: lowland rainforest, stream and riverside vegetation, fresh water swamp forest, mangrove, coastal bar forest and littoral vegetation. The multitude of vegetation type in BBCF accounts for its rich diversity of plants species with high conservation importance. The Botanic Surveys of 1992 and 1997 identified BBCF as the last remnant of coastal lowland forest between Douala and Limbe (Nuesiri, 2008). The southern portion of the forest is of conservation importance; out of 1500 specimens collected 24 were strictly endemic and 43 rare or new to science, outstanding totals given the small size of the area. The number of new species is extremely high and compares with the Amazon basin. This illustrates the importance of conserving the forest in the expectation of the discovery of other new species. Table 1 indicates the commercial non-timber forest products of the 9 compartments of the study area. Some of these products grow in the wild in combination with other trees. Most of the climbing types such as eru are found climbing on forest trees for support. They are rarely cultivated but may exist as protected stands on farmlands. As these species are not generally planted, they are therefore very susceptible to genetic erosion. Forest adjacent villagers must harvest these products for a livelihood. Overall, the table justifies the fact that this forest has rich biodiversity potentials in terms of flora.

Table 1. Plant Species found in the Different Compartments of the Forest

\begin{tabular}{|c|c|c|c|c|c|c|c|c|c|c|}
\hline \multirow[t]{2}{*}{ Species } & \multirow[t]{2}{*}{ Number } & \multicolumn{9}{|c|}{ Compartments } \\
\hline & & 1 & 2 & 3 & 4 & 5 & 6 & 7 & 8 & 9 \\
\hline Indian bamboo & Abundant & $\sqrt{ }$ & $\sqrt{ }$ & $\sqrt{ }$ & $\sqrt{ }$ & $\sqrt{ }$ & $\sqrt{ }$ & $\sqrt{ }$ & $\sqrt{ }$ & $\sqrt{ }$ \\
\hline Bush Onion & Abundant & $\sqrt{ }$ & $\sqrt{ }$ & $\sqrt{ }$ & $\sqrt{ }$ & $\sqrt{ }$ & $\sqrt{ }$ & $\sqrt{ }$ & $\sqrt{ }$ & $\sqrt{ }$ \\
\hline Njangsang & Abundant & $\sqrt{ }$ & $\sqrt{ }$ & $\sqrt{ }$ & $\sqrt{ }$ & $\sqrt{ }$ & $\sqrt{ }$ & $\sqrt{ }$ & $\sqrt{ }$ & $\sqrt{ }$ \\
\hline Bush mango & Abundant & $\sqrt{ }$ & $\sqrt{ }$ & $\sqrt{ }$ & $\sqrt{ }$ & $\sqrt{ }$ & $\sqrt{ }$ & $\sqrt{ }$ & $\sqrt{ }$ & $\sqrt{ }$ \\
\hline Bush pepper & Abundant & $\sqrt{ }$ & $\sqrt{ }$ & $\sqrt{ }$ & $\sqrt{ }$ & $\sqrt{ }$ & $\sqrt{ }$ & $\sqrt{ }$ & $\sqrt{ }$ & $\sqrt{ }$ \\
\hline Kola nuts & Abundant & $\sqrt{ }$ & $\sqrt{ }$ & $\sqrt{ }$ & $\sqrt{ }$ & $\sqrt{ }$ & $\sqrt{ }$ & $\sqrt{ }$ & $\sqrt{ }$ & $\sqrt{ }$ \\
\hline Bush carrot & Abundant & $\sqrt{ }$ & $\sqrt{ }$ & $\sqrt{ }$ & $\sqrt{ }$ & $\sqrt{ }$ & $\sqrt{ }$ & $\sqrt{ }$ & $\sqrt{ }$ & $\sqrt{ }$ \\
\hline Chewing stick & Many & $\sqrt{ }$ & $\sqrt{ }$ & $\sqrt{ }$ & $\mathrm{X}$ & $\mathrm{x}$ & $\sqrt{ }$ & $\sqrt{ }$ & $\sqrt{ }$ & $\sqrt{ }$ \\
\hline Ngongo leaf & Many & $\sqrt{ }$ & $\sqrt{ }$ & $\sqrt{ }$ & $\sqrt{ }$ & $\sqrt{ }$ & $\mathrm{x}$ & $\mathrm{x}$ & $\mathrm{x}$ & $\mathrm{x}$ \\
\hline Cashew & Many & $\mathrm{X}$ & $\mathrm{X}$ & $\mathrm{X}$ & $\mathrm{X}$ & $\mathrm{X}$ & $\sqrt{ }$ & $\sqrt{ }$ & $\sqrt{ }$ & $\sqrt{ }$ \\
\hline Monkey kola & Many & $\mathrm{x}$ & $\sqrt{ }$ & $\sqrt{ }$ & $\mathrm{x}$ & $\mathrm{x}$ & $\mathrm{x}$ & $\mathrm{X}$ & $\mathrm{x}$ & $\mathrm{x}$ \\
\hline Eru & Few & $\sqrt{ }$ & $\sqrt{ }$ & $\sqrt{ }$ & $\mathrm{X}$ & $\mathrm{X}$ & $\sqrt{ }$ & $\sqrt{ }$ & $\mathrm{x}$ & $\mathrm{x}$ \\
\hline Rattan & Few & $\sqrt{ }$ & $\sqrt{ }$ & $\sqrt{ }$ & $\sqrt{ }$ & $\sqrt{ }$ & $\mathrm{x}$ & $\mathrm{X}$ & $\mathrm{x}$ & $\mathrm{x}$ \\
\hline Kusha (sponge) & Few & $\sqrt{ }$ & $\sqrt{ }$ & $\sqrt{ }$ & $\mathrm{x}$ & $\mathrm{x}$ & $\mathrm{x}$ & $\mathrm{X}$ & $\sqrt{ }$ & $\sqrt{ }$ \\
\hline
\end{tabular}

Source: Bimbia-Bonadikombo Community Forest Management Plan $(\sqrt{ }=$ Present; $x=$ Not present $)$ 
The numerous plant species in the forest have been known to be very valuable. Table 2 presents the medicinal and economic values of plant species found in the forest. These plants highlight the value of all plants to mankind. A variety of plant parts such as roots, barks, stems and leaves are harvested for medicinal purposes and are commonly traded in the local markets.

Table 2. Some Plant Species used in BBCF for Medicinal Purposes

\begin{tabular}{|l|l|l|}
\hline Scientific names & Common names & Uses \\
\hline Aframumum spp & $\begin{array}{l}\text { Alligatorpepper } \\
\text { (mbongo) }\end{array}$ & $\begin{array}{l}\text { Grains are used as cough expectorant, used as } \\
\text { charm }\end{array}$ \\
\hline Alstonia boonei & Milk stick & $\begin{array}{l}\text { Mix root with that of mango and sterile pawpaw } \\
\text { in palm wine to treat typhoid }\end{array}$ \\
\hline Baillonella toxisperma & Moabi (njabe) & $\begin{array}{l}\text { Used to remove excess fat from the stomach of } \\
\text { infertile women }\end{array}$ \\
\hline Bryophyllum pinnatum & Yoka & $\begin{array}{l}\text { Warm leaves squeezed and dropped in painful } \\
\text { ears }\end{array}$ \\
\hline Canarium schwenfurthii & Bush plum & $\begin{array}{l}\text { Used to disinitiate people from bad societies } \\
\text { (spiritual and cultural use) }\end{array}$ \\
\hline Cieba pentandra & Boil bark and take as enema for stomach growth \\
\hline Costus aferker-gawi & Buma tree & Roots used for sleeping sickness \\
\hline Elaeis guinensis & Monkey sugar cane & Kernel oil used as poison antidote \\
\hline Garcinia mannii & Palm tree & Chew stem with salt for running stomach \\
\hline Kigeli Africana & Chewing stick & Use for conjunctivitis \\
\hline Milicia excelc & Sausage tree & Use bark for stomach problems \\
\hline Pterocapus soyauxii & Iroko & Use as skin cream \\
\hline Piper guinensis & Camwood & Stimulant \\
\hline Rauwolfia vomitoria & Bush pepper & Use for malaria treatment \\
\hline Senna alata & & Mashed leaves are used for fungal infection \\
\hline Prunus africana & Cassia & Solution from boiled bark to treat chest pain \\
\hline
\end{tabular}

Source: Field data (May, 2016).

Since medicinal plants are found in the wild and mostly in concentrated stands in forest reserves, they are foraged by local people and sold to commercial companies which use them to manufacture a wide range of health products. There has been a rapid decline in the forest ecosystem which is as a result of anthropogenic pressure mounted on the forest by the adjacent forest communities (Mesmin et al., 2009; Sunderlin, et al., 2005; Ndenecho, 2005; Sunderland et al., 2002; Balgah, 2001; Denniston, 1995). The indigenous people whose livelihood is depended upon the forest has been denied their rights to use the forest by protection status. As such, conservation policies have been violated, causing the forest resources to diminish (Mesmin et al., 2009; Mesmin \& Fogwe, 2009; Sunderlin, et al., 2005; Ndenecho, 2005; Sunderland et al., 2002; Mcneely, et al., 1990). The high pressure coupled with the importance attached to this forest as a source of livelihoods for the people makes state control of the forest to be very complex.

The increasing population and the need for money are increasingly orienting the economy from subsistence to commercial farming. NTFP collection involves the use of unsustainable harvesting techniques which contribute to rapid deterioration of the forest. Trees are ring-barked, exposing the stems and leading to death. This constitutes a threat to the use of many medical plants as future resources. Tree deaths are partly due to poor method of exploitation and the fact that the trees are illegally exploited. Some of the trees are felled and sawn using motorized saws; and used for furniture making and construction (Nuesiri, 2008). All these contribute in narrowing the forest cover and have also led to an increase in the number of threatened and endemic plant species in the BBCF. Flora species known to be endemic or under threat (rare, endangered and/or protected) and that have been identified within the BBCF are listed on Table 3.

Table 3. Threatened and Endemic Plant Species of the BBCF

\begin{tabular}{|l|l|}
\hline Species types & Plants (Scientific Names) \\
\hline \multirow{4}{*}{ Threatened } & Milletia sp, \\
\cline { 2 - 2 } & Afzelia spp, \\
\cline { 2 - 2 } & Entandrophragma spp, \\
\hline
\end{tabular}


Dr. Robert Njilla Mengnjo Ngalim \& Simbo Terence

\begin{tabular}{|l|l|}
\hline \hline \multirow{5}{*}{} & Khaya anthotheca, \\
\cline { 2 - 3 } & Nauclea diderrichi, \\
\cline { 2 - 3 } & Lophira alata, \\
\cline { 2 - 3 } & Baillonella toxisperma, \\
\cline { 2 - 3 } & Diospyros spp, \\
\cline { 2 - 3 } & Triplochiton scleroxylon \\
\cline { 2 - 3 } & Prunus africana \\
\hline & Oxygen triandra \\
\cline { 2 - 3 } & Neoschumannia kamerunensis \\
\cline { 2 - 3 } & Oxystigma mannii \\
\cline { 2 - 3 } & Afrothismia sp. \\
\hline & Pterocapus soyauxii \\
\cline { 2 - 3 } & Terminalia superba \\
\cline { 2 - 3 } & Ricinodendron heudelotii \\
\cline { 2 - 3 } & Gnetum africanum \\
\cline { 2 - 3 } & Carapa procera \\
\cline { 2 - 3 } & Ceiba pentandra \\
\cline { 2 - 3 } & Pycnantus angolensis \\
\cline { 2 - 3 } & Terminalia superba \\
\cline { 2 - 3 } & Coelocaryon preussii \\
\cline { 2 - 3 } & Irvingia gabonensis \\
\hline
\end{tabular}

Source: Bimbia-Bonadikombo Community Forest Management Plan Document.

\section{Fauna}

The loss of forest vegetation is a common occurrence in the Bimbia-Bonadikombo Community Forest. Drills (Mandrillus leucophaeus), chimpanzees and other mammals are said to have been almost extinct in the forest (Jaff, 1994). The Mona monkey remains relatively common although a target for hunters. Other wildlife species are found in the forest despite the fact that they are facing a lot of anthropogenic pressure. These include: cane rat, brush tail porcupine, blue duiker, African civet, viper, monitor lizard and squirrel. Other species such as antelope, dwarf crocodile, pangolin, tree hyrax, tortoise and African rock python are also facing extinction in the forest. The problem is further compounded by habitat loss, which is suffered most by birds and monkeys as a result of hunting and logging. The wildlife resources in the different compartments of the BBCF are presented on Table 4.

Table 4. Fauna Species found in the Different Compartments of the BBCF

\begin{tabular}{|c|c|c|c|c|c|c|c|c|c|c|}
\hline \multirow[t]{2}{*}{ Species } & \multirow[t]{2}{*}{ Number } & \multicolumn{9}{|c|}{ Compartments } \\
\hline & & 1 & 2 & 3 & 4 & 5 & 6 & 7 & 8 & 9 \\
\hline Cane rat & Abundant & $\mathrm{X}$ & $\sqrt{ }$ & $\sqrt{ }$ & $\mathrm{x}$ & $\mathrm{x}$ & $\mathrm{x}$ & $\sqrt{ }$ & $\mathrm{x}$ & $\mathrm{x}$ \\
\hline Mona monkey & Abundant & $\sqrt{ }$ & $\sqrt{ }$ & $\sqrt{ }$ & $\sqrt{ }$ & $\sqrt{ }$ & $\sqrt{ }$ & $\sqrt{ }$ & $\sqrt{ }$ & $\sqrt{ }$ \\
\hline Monitor Lizard & Abundant & $\sqrt{ }$ & $\sqrt{ }$ & $\sqrt{ }$ & $\sqrt{ }$ & $\sqrt{ }$ & $\sqrt{ }$ & $\sqrt{ }$ & $\sqrt{ }$ & $\sqrt{ }$ \\
\hline Squirrel & Abundant & $\sqrt{ }$ & $\sqrt{ }$ & $\sqrt{ }$ & $\sqrt{ }$ & $\sqrt{ }$ & $\sqrt{ }$ & $\sqrt{ }$ & $\sqrt{ }$ & $\sqrt{ }$ \\
\hline Bush tail porcupine & Abundant & $\sqrt{ }$ & $\sqrt{ }$ & $\sqrt{ }$ & $\sqrt{ }$ & $\sqrt{ }$ & $\sqrt{ }$ & $\sqrt{ }$ & $\sqrt{ }$ & $\sqrt{ }$ \\
\hline Red-tailed Monkey & Many & $\sqrt{ }$ & $\sqrt{ }$ & $\sqrt{ }$ & $\sqrt{ }$ & $\sqrt{ }$ & $\sqrt{ }$ & $\sqrt{ }$ & $\sqrt{ }$ & $\sqrt{ }$ \\
\hline White-nosed monkey & Many & $\sqrt{ }$ & $\sqrt{ }$ & $\sqrt{ }$ & $\mathrm{x}$ & $\mathrm{x}$ & $\sqrt{ }$ & $\sqrt{ }$ & $\mathrm{x}$ & $\mathrm{x}$ \\
\hline Blue duiker & Many & $\sqrt{ }$ & $\sqrt{ }$ & $\sqrt{ }$ & $\sqrt{ }$ & $\sqrt{ }$ & $\sqrt{ }$ & $\sqrt{ }$ & $\sqrt{ }$ & $\sqrt{ }$ \\
\hline African civert & Many & $\sqrt{ }$ & $\sqrt{ }$ & $\sqrt{ }$ & $\sqrt{ }$ & $\sqrt{ }$ & $\sqrt{ }$ & $\sqrt{ }$ & $\sqrt{ }$ & $\sqrt{ }$ \\
\hline Viper & Many & $\sqrt{ }$ & $\sqrt{ }$ & $\sqrt{ }$ & $\sqrt{ }$ & $\sqrt{ }$ & $\sqrt{ }$ & $\sqrt{ }$ & $\sqrt{ }$ & $\sqrt{ }$ \\
\hline Antelope & Few & $\sqrt{ }$ & $\mathrm{x}$ & $\mathrm{X}$ & $\mathrm{x}$ & $\mathrm{x}$ & $\mathrm{X}$ & $\sqrt{ }$ & $\mathrm{x}$ & $\mathrm{X}$ \\
\hline Dwarf crocodile & Few & $\sqrt{ }$ & $\mathrm{x}$ & $\mathrm{X}$ & $\mathrm{x}$ & $\mathrm{x}$ & $\sqrt{ }$ & $\sqrt{ }$ & $\sqrt{ }$ & $\sqrt{ }$ \\
\hline Pangoline & Few & $\sqrt{ }$ & $\sqrt{ }$ & $\sqrt{ }$ & $\sqrt{ }$ & $\sqrt{ }$ & $\sqrt{ }$ & $\sqrt{ }$ & $\sqrt{ }$ & $\sqrt{ }$ \\
\hline Tree Hydrax & Few & $\sqrt{ }$ & $\sqrt{ }$ & $\sqrt{ }$ & $\sqrt{ }$ & $\sqrt{ }$ & $\sqrt{ }$ & $\sqrt{ }$ & $\sqrt{ }$ & $\sqrt{ }$ \\
\hline Galagose pottos & Few & $\sqrt{ }$ & $\sqrt{ }$ & $\sqrt{ }$ & $\sqrt{ }$ & $\sqrt{ }$ & $\sqrt{ }$ & $\sqrt{ }$ & $\sqrt{ }$ & $\sqrt{ }$ \\
\hline Tortoise & Few & $\sqrt{ }$ & $\sqrt{ }$ & $\sqrt{ }$ & $\mathrm{x}$ & $\mathrm{x}$ & $\sqrt{ }$ & $\sqrt{ }$ & $\mathrm{x}$ & $\mathrm{x}$ \\
\hline African Rock Python & Few & $\sqrt{ }$ & $\sqrt{ }$ & $\sqrt{ }$ & $\sqrt{ }$ & $\sqrt{ }$ & $\sqrt{ }$ & $\sqrt{ }$ & $\sqrt{ }$ & $\sqrt{ }$ \\
\hline Drill & Very few & $\mathrm{x}$ & $\sqrt{ }$ & $\sqrt{ }$ & $\mathrm{x}$ & $\mathrm{x}$ & $\mathrm{x}$ & $\mathrm{x}$ & $\mathrm{x}$ & $\mathrm{x}$ \\
\hline
\end{tabular}

Source: Bimbia-Bonadikombo Community Forest Management Plan $(\sqrt{ }=$ Present; $x=$ Not present $)$

Fauna species known to be endemic or under threat (rare, endangered and/or protected) and that have been identified within the BBCF are listed on Table 5. 
The Bimbia-Bonadikombo Community Forest, South West Region of Cameroon: Biodiversity Potentials, Problems and Prospects

Table 5. Threatened and Endemic Animal Species of the BBCF

\begin{tabular}{|c|c|}
\hline Species types & Animals (Scientific Names) \\
\hline \multirow{8}{*}{ Threatened } & Pan troglodytes, \\
\hline & Python sebae, \\
\hline & Ostealemus tetracus \\
\hline & Chelonia mydas, \\
\hline & Eretmochelys imbricata, \\
\hline & Lepidochelys olivacea, \\
\hline & Dermochelys coriacea, \\
\hline & Caretta caretta \\
\hline \multirow{10}{*}{ Endemic } & Papio leucophaeus (class A), \\
\hline & Pan troglodytes $(\mathrm{A})$ \\
\hline & Ostealemus tetracus ( A) \\
\hline & Vivera civetta ( B) \\
\hline & Python sebae (B) \\
\hline & Chelonia mydas (A) \\
\hline & Eretmochelys imbricate (A) \\
\hline & Lepidochelys olivacea (A) \\
\hline & Dermochelys coriacea (A) \\
\hline & Caretta caretta $(\mathrm{A})$ \\
\hline
\end{tabular}

Source: Simple Management Plan for BBCF for the period $2002-2027$

The classification of endemism according to Classes A or B is based on that of the International Union for the Conservation of Nature (IUCN).

\section{Livelihood Activities}

Experience has revealed that the local population around any protected forest are compelled to violate protection laws in order to survive by encroaching into such protected areas. The BBCF is therefore not an exception. Several livelihood activities are carried out within the forest. Palm oil production is a recurrent activity within the confines of the BBCF due to the presence of palm plantations (Plate 1). This activity is detrimental to the forest in that fuel wood used in the process is harvested from the same forest.

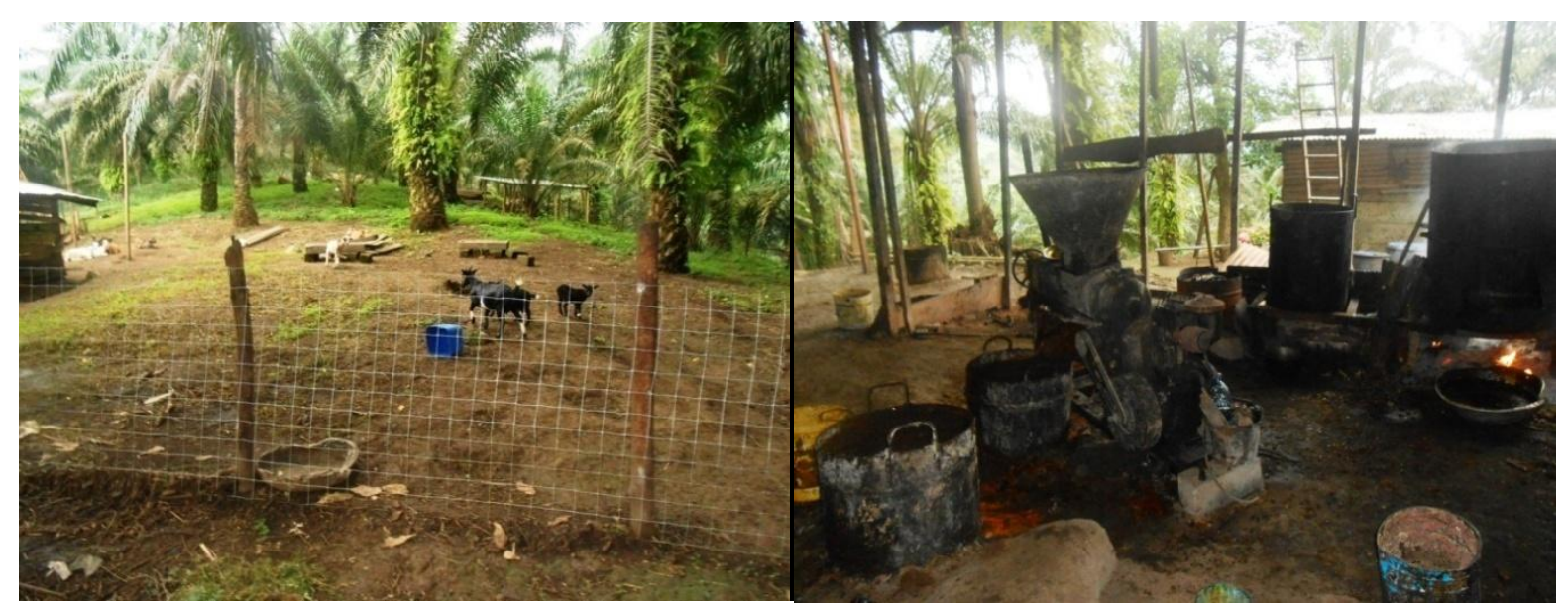

Plate 1. Livelihood activities within the BBCF boundaries (A) Palms plantation and small scale animal rearing (B) Oil palm production within the $B B C F$.

Source: Field work (June, 2016)

Timber exploitation in the BBCF has evolved through three phases in the last decades, viz: industrial logging destined for export, followed by the first phase of small-scale timber exploitation by chainsaw owners. Timber is used for furniture, building and roofing of houses in Limbe, Bimbia-Bonadikombo villages, Tiko and CDC camps around the area. Tree species exploited in the forest include Iroko, Mahogany, White wood and Afara. The scarcity of the high quality timber has made exploiters to resort to the exploitation of secondary species namely: Staudtia stipitata and various species of Myristicaceae. 


\section{Dr. Robert Njilla Mengnjo Ngalim \& Simbo Terence}

Furthermore, for over a decade, the demand for charcoal has increased very rapidly. Many young men and women began the exploitation of iron wood (Lophira alata). The process entails felling of trees, crosscutting, splitting and burning (Nuesiri, 2008). Huge logs are felled, chopped into small sizes, buried in a large hole dug in the ground and covered with grasses and earth. A small vent is allowed for the smoke to escape. The logs in the hole are then set on fire, some of which could burn continuously for weeks. When there is no smoke escaping from the vent, it therefore means that all the biomass has completely burned. The fire is extinguished with water and the charcoal removed from the hole. The effects are devastating not only in terms of biodiversity and flora destruction, but also in terms of microorganism destruction. As such, the soils around the charcoal producing sites are not favourable for agricultural production.

Also, there is the construction of houses and farming activities undertaken within the BBCF boundaries. Most houses in this area are constructed using timber exploited from the forest. Some of these houses are constructed for economic purpose such as the poultry on Plate $2 \mathrm{~A}$, and a farm house for milling palm oil (Plate 1). Some of these activities are conducted illegally deep into the forest where the perpetuators believe they can escape from the forest guards. Subsistence farming is carried out in this forest due to its rich fertile soils. As such, the population indulge in mixed farming cultivating crops such as maize, cassava, bananas, plantains and palms on the same piece of land (Plate 2B).

The community also exploits non-timber forest products (NTFPs) for home use and marketing. NTFPs found in the forest are mostly spices such as eru, bitter kola (Garcinia kola) bush pepper (Piper guinensis), and bush mango (Irvingia gabonensis). NTFPs are planted and harvested by the local community. These are especially very important to local women who collect either for household consumption or for sale in the local markets. This exploitation has contributed significantly to providing employment especially for youths in the area. Table 6 reveals the variety of community forest resources, their main uses and secondary uses.



Plate 2. Human activities within the BBCF boundaries (A) Poultry constructed with wood from the $B B C F(B)$ Mixed farming of maize, cassava, banana, plantains and palms within the BBCF boundaries

Source: Field work (June, 2016)

Table 6. Community Forest Uses

\begin{tabular}{|l|l|l|l|l|}
\hline Compartment & Area & Main Uses & Resources & Secondary Uses \\
\hline $\begin{array}{l}\text { Dikolo } \\
\text { Peninsular }\end{array}$ & $\begin{array}{l}250 \\
\text { ha }\end{array}$ & $\begin{array}{l}\text {-Ecotourism } \\
\text { - Research }\end{array}$ & $\begin{array}{l}\text { - Mangrove } \\
\text {-Wildlife: white-nosed monkey, } \\
\text { dwarf crocodile, monitor lizard, } \\
\text {-Timber: Lophira alata, } \\
\text { Terminalia, Staudtia, Ceiba }\end{array}$ & $\begin{array}{l}\text { Collection of minor forest } \\
\text { products, Indian bamboo, } \\
\text { bush onion, bush mango, } \\
\text { bush pepper, njangsang }\end{array}$ \\
\hline $\begin{array}{l}\text { Likomba La- } \\
\text { mbenge }\end{array}$ & $\begin{array}{l}334 \\
\text { ha }\end{array}$ & $\begin{array}{l}\text { - Research } \\
\text {-Beekeeping }\end{array}$ & $\begin{array}{l}\text {-Wildlife: cane rat, red-tailed } \\
\text { monkey, viper, squirrel } \\
\text {-Timber Lophira alata, } \\
\text { Desbordesia glaucescens, } \\
\text { Entandrophragma spp. }\end{array}$ & $\begin{array}{l}\text { Sustainable collection of } \\
\text { NTFPs (rattan, chewing } \\
\text { stick, bush onion, bush } \\
\text { mango, bush carrot) }\end{array}$ \\
\hline $\begin{array}{l}\text { Likomba La- } \\
\text { Lelu }\end{array}$ & $\begin{array}{l}645 \\
\text { ha }\end{array}$ & $\begin{array}{l}\text { - Research } \\
\text {-Beekeeping } \\
\text { monkey, viper, rat, red-tailed } \\
\text {-Timber: Lophira alata, }\end{array}$ & $\begin{array}{l}\text { Sustainable collection of } \\
\text { NTFPs (chewing stick, } \\
\text { bush onion, bush mango, }\end{array}$ \\
\hline
\end{tabular}


The Bimbia-Bonadikombo Community Forest, South West Region of Cameroon: Biodiversity Potentials, Problems and Prospects

\begin{tabular}{|c|c|c|c|c|}
\hline Compartment & Area & Main Uses & Resources & Secondary Uses \\
\hline & & & $\begin{array}{l}\text { Desbordesia glaucescens, } \\
\text { Entandrophragma spp. }\end{array}$ & bush, carrot) \\
\hline Bimbia & $\begin{array}{l}252 \\
\text { ha }\end{array}$ & $\begin{array}{l}\text {-Beekeeping } \\
\text {-Commercial } \\
\text { fuelwood } \\
\text { extraction }\end{array}$ & $\begin{array}{l}\text {-Wildlife: Red-tailed monkey, } \\
\text { mona monkey, monitor lizard } \\
\text {-Timber: Alstonia congensis, } \\
\text { Coelocaryon preussii, } \\
\text { Erithroxylum ivorense }\end{array}$ & $\begin{array}{l}\text {-Charcoal burning } \\
\text {-Collection of NTFPs } \\
\text { (bush onion, bush mango, } \\
\text { bush, njangsang) }\end{array}$ \\
\hline $\begin{array}{l}\text { Mawoh } \\
\text { Motondo }\end{array}$ & $\begin{array}{l}229 \\
\text { ha }\end{array}$ & $\begin{array}{l}\text {-Charcoal burning } \\
\text {-Commercial } \\
\text { fuelwood } \\
\text { extraction }\end{array}$ & $\begin{array}{l}\text {-Wildlife: Red tailed monkey, } \\
\text { mona monkey, brush tailed } \\
\text { porcupine, squirrel }\end{array}$ & $\begin{array}{l}\text {-Beekeeping } \\
\text {-Collection of NTFPs } \\
\text { (bush onion, bush mango, } \\
\text { bush, njangsang) }\end{array}$ \\
\hline Liwanda & $\begin{array}{l}286 \\
\text { ha }\end{array}$ & $\begin{array}{l}\text {-Commercial } \\
\text { fuelwood } \\
\text { extraction }\end{array}$ & 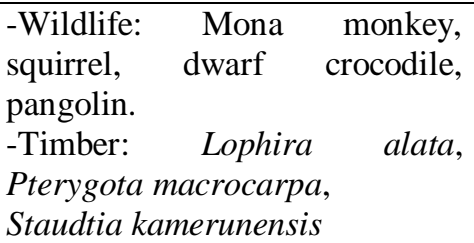 & $\begin{array}{l}\text {-Beekeeping } \\
\text {-Agroforestry } \\
\text { - Sustainable collection of } \\
\text { NTFPs (chewing stick, } \\
\text { bush onion, bush mango) }\end{array}$ \\
\hline Bamukong & $\begin{array}{l}774 \\
\text { ha }\end{array}$ & $\begin{array}{l}\text {-Timber } \\
\text { exploitation } \\
\text {-Bee farming }\end{array}$ & $\begin{array}{l}\text {-Wildlife: cane rat, white nosed } \\
\text { monkey, antelope, tortoise } \\
\text {-Timber: Lophira alata, } \\
\text { Terminalia superba }\end{array}$ & $\begin{array}{l}\text {-Collection of NTFPs } \\
\text { (bush onion, bush mango, } \\
\text { bush, njangsang, eru) }\end{array}$ \\
\hline Moliwe Hills & $\begin{array}{l}565 \\
\text { ha }\end{array}$ & $\begin{array}{l}\text {-Timber } \\
\text { exploitation } \\
\text {-Bee farming }\end{array}$ & $\begin{array}{l}\text {-Wildlife: Mona monkey, } \\
\text { pangolin } \\
\text {-Timber: Afzelia bipendensis, } \\
\text { Dacryodes edulis, Coelocaryon } \\
\text { preussii }\end{array}$ & $\begin{array}{l}\text {-Collection of NTFPs } \\
\text { (bush onion, bush mango, } \\
\text { bush, njangsang, eru) }\end{array}$ \\
\hline Bonadikombo & $\begin{array}{l}400 \\
\text { ha }\end{array}$ & $\begin{array}{l}\text {-Timber } \\
\text { exploitation } \\
\text {-Bee farming }\end{array}$ & $\begin{array}{lcc}\text {-Wildlife: } & \text { pangolin, } & \text { viper, } \\
\text { squirrel, } & & \\
\text {-Timber: Lophira } & \text { alata, } \\
\text { Ricinodendron heudelotti } & \end{array}$ & $\begin{array}{l}\text {-Collection of NTFPs } \\
\text { (bush onion, bush mango, } \\
\text { bush, njangsang, eru) }\end{array}$ \\
\hline
\end{tabular}

Source: Simple Management Plan for BBCF for the period 2002 - 2027

\section{Forests as the Last Vestiges of the gods (Spiritual importance)}

The forest has also served as an area where some traditions and rituals are implemented. Traditional rites are carried out in certain parts of the forest, notably in Bimbia; certain places were used as burial grounds. Native (traditional) doctors used the forest to prepare traditional medicines. A variety of plants are collected from the forest by traditional doctors for the cure of common illnesses such as headache, malaria, typhoid, epilepsy. Livelihood activities are therefore encroaching into the reserves and protected areas. Non-Timber Forest Product (NTFP) collection, fishing, hunting and timber exploitation are amongst the top priorities of the local people from the forest. These are well protected by the beliefs and traditions of the indigenous population (Lambi et al., 2012; Lambi and Ndenecho, 2006). There is the location of shrines or sacred places in the forests where traditional practices and rituals tied to the traditions and customs of the indigenes are performed.

\section{The Customary and Logging User Rights}

The customary rights covered in the Bimbia-Bonadikombo Community Forest include forest products, wildlife, fisheries products and other secondary forest products. The products resulting from the exercise of customary user rights cannot be commercialized or sold. The Bimbia-Bonadikombo Natural Resource Management Council (BBNRMC) gives preferences on customary and logging user rights to villages adjacent to the forest. Applications for exercise of customary rights are forwarded to the Bimbia-Bonadikombo Natural Resource Management Council. All applications are followed by an inspection to the site. Permits for user rights are issued free of charge based on the motive for personal use in the village. If a member of BBNRMC wants to construct out of the village, carry out hunting or exploit fuel wood for commercial purpose they should follow the procedure found in the management agreement. The BBNRMC retains the right to temporarily suspend or restrict customary user rights pronounced after the adoption of the proposal by the General Assembly for the purposes of conservation or others as need be. Though a conservation strategy, this is an importance livelihood sustenance component of the BBCF since it gives the right to exploit to the users. 
To further enhance the livelihood motive of the forest, the members of the Bimbia-Bonadikombo Community have the following rights with permission from BBNRMC:

- Single tree-felling rights for local construction

- Commercial fuel wood exploitation

- All types of hunting

Without needing to seek permission of the BBNRMC, the following activities are allowed:

- The right to collect fuel wood for subsistence

- Collection of NTFPs for consumption

- Fishing rights

- Traditional rights, rituals, rites for village harmony, sacrifices, among others.

The above are strategies meant to enhance the livelihood of the forest adjacent populations while systematically safeguarding the conservation of the forest ecosystem. The above strategies acknowledge the fact that the forest is the bona fide gift of these inhabitants and therefore their livelihoods and sustenance are somehow tied to the forest. This explains why the population exploits and utilises some non-timber forest products exploited from the forest. This is a form of participatory approach based on the involvement of the local population not only in conservation activities, but in livelihood and exploitation activities.

\section{Land Tenure and Conflicts}

The majority of the land in Bimbia-Bonadikombo is on long term lease from the state by the Cameroon Development Corporation (CDC). The CDC has developed rubber and palms plantations within the confines of the forest. The claim CDC has over the forest represents the de jure rights of ownership. The legal pluralisms in the Bimbia-Bonadikombo forest are complex and diverse as well as the concept of ownership in the Bimbia-Bonadikombo forest as the stakeholders concerned are also numerous. This has resulted to conflicts of ownership and usage (Orock and Kometa, 2009). The forest adjacent villages of Bonangombe, Dikollo, Bonabile, and Bonadikombo, lay traditional claims over the land under customary tenure, representing the de facto claim over the land. Individuals also lay claims to the forest (Plate 3). The Limbe Botanic and Rainforest Genetic Conservation Project (LBGRCP) in the period 1988-1991 demarcated the boundaries of the forest after a reconnaissance visit and carried out a Botanical Inventory in 1992. These inventories were carried out to assess the resources of the forest, but this was never materialized (Jaff, 1994).
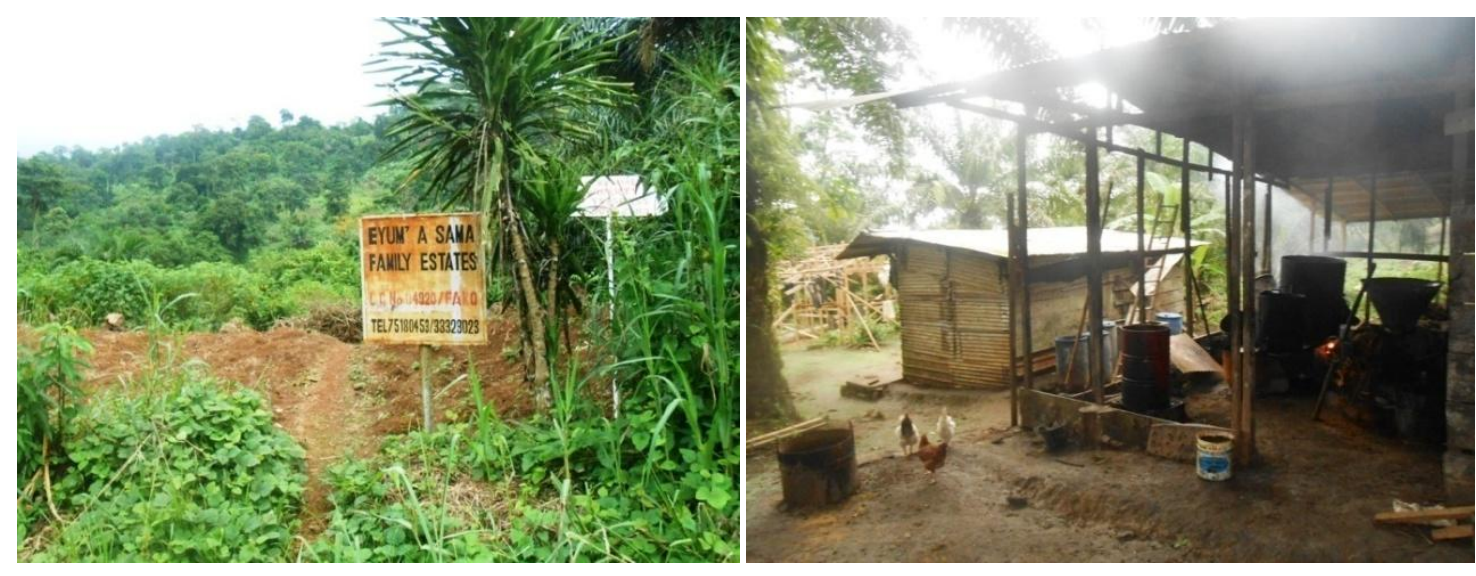

Plate 3: Land tenure conflicts with BBCF boundaries (A) A Family's claim of ownership of land within the $\mathrm{BBCF}$ boundaries (B) Housing construction using wood from the forest within the BBCF.

Source: Field work (June, 2016)

However, the Cameroon Land Ordinance No. 74-1 of July 6, 1974 maintains that the State is the guardian of all lands, even though traditional authorities continue to exercise de facto rights over land. In the Mt. Cameroon Region, the indigenous Bakweris are locked in a legal battle against the Cameroonian government to reclaim the lands hosting the government-owned agricultural plantations. These plantations were initially set up during the colonial era by European entrepreneurs but were 
released to the government of Cameroon after independence. The Bakweris claim the land was expropriated from them by the Germans without compensation, and are thus demanding that this land be returned to them (Nuesiri, 2008). In the Bimbia-Bonadikombo vicinity, however, the immigrants who depend substantially on the forest for their local livelihoods cannot obtain de jure or de facto rights over the land. The precarious land tenure problem makes the non-indigenes unable to fully accept participatory forest management as a lasting solution since they do not have any rights as regards land ownership. This has been one of the main reasons for the increasing proliferation of illicit activities within the Bimbia-Bonadikombo Community Forest.

\section{SWOT Analysis}

In order to appraise and identify the views of the inhabitants with regards to forest exploitation and management, a SWOT analysis was conducted involving the total inhabitants of the area and the members of the forest management committee. This was a focused-group discussion style meeting aimed at probing the population on the biodiversity potentials of the forest, their strengths, weaknesses, opportunities and threats. The Bimbia-Bonadikombo Community Forest is rich with biodiversity potentials. The strengths $(\mathrm{S})$, weaknesses $(\mathrm{W})$, opportunities $(\mathrm{O})$ and threats $(\mathrm{T})$ of the resources were identified: Since the forest management committee members were also members of the community and users of the forest, their views with regards to SWOT were not different from the inhabitants. However, the committee members mostly highlighted issues related to management of the forest, while the indigenous population highlighted issues related to exploitation and utilisation of the forest.

\section{Strengths}

- The area is rich in biodiversity (plants and animals) and natural landscape of touristic and scientific importance, as has already been illustrated above.

- Local people are welcoming and have a positive attitude towards conservation.

- It possesses rich cultural values, rites, festivals, settlements, foods and houses.

- Annual festivals are organized in the area.

- Life is traditional and tranquil in a typical African setting.

- This area has an ecological potential to increase for worldwide and local ecotourism.

- Presence of expertise in the Limbe Wildlife Centre and the Botanic Garden.

- Availability of planning documents.

\section{Weaknesses}

- Local people are insensitive to environmental issues.

- The reserve is grossly under-staffed with not up to 10 staff.

- The area is enclaved with difficult topography.

- Tourism is the region is very backward with no advertisement, marketing activities and agencies.

- The master management and development plan to take advantage of the resources offered by the area are not being implemented.

- Continuous proliferation of illicit activities within the confines of the BBCF due to insufficient monitoring by the BBCFMC.

\section{Opportunities}

- Integrating livelihoods in conservation projects for local employment and poverty alleviation.

- Promoting the participation of local people in biodiversity protection.

- Protecting and sustaining the rich biodiversity of the area.

- Promoting tourism and biodiversity conservation by linking culture, the environment and livelihoods. 
- Biodiversity management

- Ecotourism tours

- Agroforestry for fuel wood production

- Domestication of NTFPs especially Eru and mushrooms

- Introduction of snail farming and the domestication of cane rates as sources of protein.

\section{Threats}

- Increasing human pressure on fauna, flora and the natural landscape.

- Absence of infrastructure and waste disposal systems.

- Poorly structured and unplanned village settlements.

- Underdeveloped environmental consciousness and threat of pollution.

- Risk from catastrophic landslides and wave erosion from the Atlantic Ocean.

- Slash and burn agriculture.

- Poaching.

- Charcoal production.

- Fuel wood production.

- Timber exploitation.

- NTFP unsustainable harvesting techniques.

- Unsustainable hunting and fishing techniques.

- Fish smoking leading to high consumption of forests for fuel wood.

There is therefore a need for an innovative project for the development of ecotourism, alleviating the impacts and maximizing the income generating impact of the forest. The Bimbia-Bonadikombo area is the home of people who continue to use forest resources in a traditional way. The area should be divided into different zones, for example, intensive farming land in the multipurpose use area, special management zones in the core and buffer zones, protected areas with high biological richness in the core zone, protected areas with high cultural richness in the multi-use areas (villages) and wilderness area in the high peaks. This is an indication that there can be no meaningful conservation without the active involvement of the local people. Conservation staff can be trained in lodge management, hygiene and marketing. Forest guards should be recruited to work in the reserve. Social amenities should be provided. Recreation should be planned throughout the year, while protecting natural habitats and local cultural heritage.

\section{CONCLUSION}

Cameroon like other countries, has established forest reserves or protected areas as a means of conserving biodiversity. In situations where the decisions of the indigenous population are ignored and the forests are not efficiently protected, conservation laws are doomed to fail. Careful planning and investments are required to overcome the weaknesses and threats. In planning the management of reserves, attention should be paid on the needs of the indigenous population that is, integrating their culture, livelihoods and environmental awareness in conservation projects. Recognizing that some of the forest products are no longer in abundance, the Bimbia-Bonadikombo community decided to take practical steps towards regulating exploitation of these forest resources. This initiative was championed by the Paramount Chief of Limbe who created a committee to monitor developments in the forest. The committee put in place was called Victoria Lands and Forest Conservation Committee (VLFCC). The committee was composed of indigenes aiming at protecting their natural resources. The VLFCC worked in close collaboration with the government through Ministry of Forestry (MINEF) and the Mount Cameroon Project (MCP) in managing the forest. Through this way, villages can learn how to manage their biodiversity in a sustainable manner, making appropriate livelihood decisions without sacrificing their cultural heritage. 
Studies in some developing countries have revealed the most costly and least effective mechanism for enforcing laws, by and large, is to rely on state governance (Ndenecho, 2005; Denniston, 1995). The difficulties of enforcing prohibitions on the use of state forests have been noted in many Sub-Saharan African countries where most forests with protection status exist only on paper. Forest protection projects that ignore local livelihoods are bound to fail (Nuesiri, 2008; Lambi and Ndenecho, 2006). This study recommends that community sanctions are ideal mechanisms for the "enforcement" through voluntary agreement of rights within fairly small and defined communities. They are more likely to put the livelihood of the indigenous forest population as top priority, in order to be effective, and to be sustainable in and socio-economic terms (Arnold and Campbell, 1985).

\section{The Way Forward}

Some suggestions to ensure sustainability in the management of the forest include: minimizing the use of scarce resources such as wood and water, develop defined trails and camp sites in the reserve, sensitize visitors and the indigenous people not to harass wildlife or disturb plant life, the local population should be encouraged to protect their environments.

Furthermore, training, sensitization and education of communities on sustainable harvesting of NTFP, domestication of wild plant species, agro-forestry for fuel wood and other usages, identification of protected resources, monitoring of biodiversity and environmental friendly practices are highly recommended as best practices for sustainable forest management and conservation in the BimbiaBonadikombo Community Forest area.

\section{REFERENCES}

[1] Arnold, J. and Campbell, J. (1985). Collective management of hill forest in Nepal; community forest project. Washington D.C.

[2] Balgah, S. N. (2001). Exploitation and conservation of biological resources in Mount Cameroon region. In, C.M. Lambi and E.B. Eze (eds). Readings in Geography, Unique printers Bamenda

[3] Biodiversity Management Plans of HCV Bimbia-Bonadikombo Community Forest (BBCF) Forest Stewardship Council - National Initiative Cameroon.

[4] CAMPER/USAID (1993). USAID Cameroon Programme for Environmental Reform, CAMPER, Yaounde.

[5] Delénè, V., Mesmin, T. and Fogwe Z. (2009). Forest Exploitation in Cameroon: Stakes and Current Challenges. In Lambi, C.M. (Editor), Cameroon: A Country At Crises Crossroads An Anthology in the Social Sciences, NAB Ventures, Bamenda, Cameroon. pp. 223-236, ISBN: 9956-420-18-2.

[6] Denniston, D. (1995). Sustaining Mountain People and Environments. Worldwatch Institute. W.W. Norton and Company, London.

[7] Hawkins, P. and Brunt, M. (1965). Soils and Ecology of West Cameroon, Rome: FAO Report.

[8] Jaff, B. (1994). Management of protected areas with particular attention to poaching and cross border cooperation in South west province, Unpublished presented paper presented in the regional Concertation on the Environment in Buea, MINEF, Yaounde, March 1994

[9] Lambi, C.M. and Ndenecho, E.N. (2006). Threats to Biological Diversity Management in the Mount Cameroon Region, Langaa Research and Publishing CIG, Mankon, Bamenda.

[10] Lambi, C. M., Kimengsi, J. N., Kometa, C. G. \& Tata, E. S. (2012). The Management and Challenges of Protected Areas and the Sustenance of Local Livelihoods in Cameroon. Environment and Natural Resources Research; Vol. 2, No. 3; 2012. ISSN 1927-0488 E-ISSN 1927-0496 Published by Canadian Centre of Science and Education

[11] Mesmin, T., Fogwe, Z., and Kengne, F. (2009). Cameroon as a Country of Under-Exploited Touristic Potentials. In Lambi, C.M. (Editor), Cameroon: A Country At Crises Crossroads An Anthology in the Social Sciences, NAB Ventures, Bamenda, Cameroon. pp. 185-196, ISBN: 9956-420-18-2.

[12] Mesmin, T. and Fogwe, Z. (2009). Ecotourism in Protected Areas of Cameroon: Trends, Problems and Prospects. In Lambi, C.M. (Editor), Cameroon: A Country At Crises Crossroads An Anthology in the Social Sciences, NAB Ventures, Bamenda, Cameroon. pp. 197-222, ISBN: 9956-420-18-2. 
[13] Mcneely, J. et al (1990). Conserve the World's Biological Diversity. IUCN/World Bank, Washington D.C.

[14] Ndenecho, E.N. (2005). Conserving biodiversity in Africa: Wildlife management in Cameroon. Loyola Journal of Social Sciences.

[15] Ndenecho, E.N. (2007). Population dynamics, rural livelihoods and forest protection projects in sub-Saharan Africa: experiences from Santa, Cameroon, International Journal of Sustainable Development and World Ecology.

[16] Nuesiri, E.O. (2008). Forest Governance Challenges on Mount Cameroon: Magazine of the International Human Dimensions Programme on Global Environmental Change, Issue 2.

[17] Nuesiri, E.O. (2008). Sustainable Livelihood Framework and Forest Management on Mt. Cameroon: Square Peg in a Round Hole? Sustainable Livelihoods Framework: Ten Years of Researching the Poor. African Environments Programme, Oxford University Centre for the Environment (OUCE), 24 January 2008

[18] Orock, F.T. and Kometa, C.G. (2009). Conflict Management in the Bimbia - Bonadikombo Community Forest. In Conflict Prevention, Management and Resolution. Proceedings of the Second Post-graduate Seminar Organised by the Faculty of Social and Management Sciences of the University of Buea, Cameroon. $28^{\text {th }}$ Jan., 2009, pp. 133-146. Printed by Agwecams Printers, Bamenda, Cameroon.

[19] Simple Management Plan for Bimbia-Bonadikombo Community Forest for the period 2002 2027.

[20] Sunderland, T.C.H., Besong, S. \& Ayeni, J.S.O. (2002). Distribution, Utilisation and Sustainability of the Non-timber Forest Products of the Takamanda Forest Reserve, Cameroon. A Consultancy Report for the Project: "Protection of the Forests around Akwaya" (PROFA).

[21] Sunderlin, W.D., Angelsen, A., Belcher, B., Burgers, P., Nasi, R., Santoso, L., \& Wunder, S. (2005). Livelihoods, Forests, and Conservation in Developing Countries: An Overview. World Development Vol. 33, No. 9, pp. 1383-1402. Elsevier Ltd. Great Britain.

[22] www.fsc.org:Forest Stewardship Council: National Initiative Cameroon FSC - CMR: Biodiversity Management Plans of HCV Bimbia-Bonadikombo Community Forest (BBCF).

\section{AUTHORS' BIOGRAPHY}

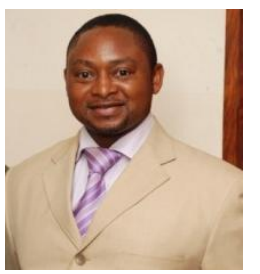

Dr. Robert Njilla Mengnjo Ngalim holds a Bachelor of Science (B.Sc. Hons) Degree, Master of Science (M.Sc.) Degree in Geography with specialisation in Environment and Natural Resource Management and a Doctor of Philosophy (Ph.D.) Degree in Geography with specialisation in Natural Resources Management from the University of Buea, Republic of Cameroon. Dr. Njilla is a Lecturer / Consultant on Specified Assignment, Department of Development Studies, Regional Planning and Project Management programme at the Pan African Institute for Development West Africa (PAID-WA), Buea. He is also the Coordinator for Research in the same Institution. Dr. Njilla has published several articles in peer-reviewed learned academic journals in Cameroon and abroad. His research interest include aspects such as Applied Physical Geography, Hydrology and Water Resources Management, Geography of Resources and Environmental management, Contemporary Issues in the $21^{\text {st }}$ Century with particular interest in Climate Change related impacts, and Modern Techniques in Geographic Research and Data Analysis, amongst others. Dr. Njilla is also a Freelance Researcher and Consultant on Environmental and Developmental Issues affecting humankind today.

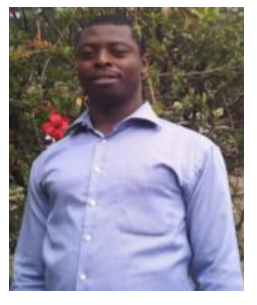

Mr. Simbo Terence holds a Bachelor of Science (B.Sc. Hons) Degree from the University of Buea, Republic of Cameroon and a Higher Teacher's Training Diploma (DIPES II) in Geography from the Higher Teachers' Training College (HTTC), Bambili of the University of Bamenda, Cameroon. Mr. Simbo is an Advanced Level Geography Tutor in the Government Bilingual Secondary School Melenka, Lebialem Division, South West, Region of Cameroon. His research areas include geomorphology and applied physical geography. 